\title{
Vyjadřování českých vidů v hospodářské němčině
}

\author{
Věra Höppnerová
}

\begin{abstract}
Abstrakt: Ačkoliv v němčině nepatří kategorie vidu k základním příznakům každého slovesa, existuje zde řada jednoduchých i složitějších prostředků, jak průběh děje vyjádřit. Porovnáním českých a německých paralelních textů německého hospodářského tisku byla zjištěna řada výrazových prostředků pro vyjadřování aspektuality, z nichž některým dosud nebyla v odborné literatuře věnována pozornost. Jejich četnost se v odborném a obecném jazyce značně liší. Současně je upozorňováno na nebezpečí interlingvální interference, ke které při oboustranném překladu nutně dochází.
\end{abstract}

Klíčová slova: český a německý hospodářský jazyk, prostř̌edky vyjadřování vidu, interlingvální interference

\begin{abstract}
In German the category of aspect does not belong to the basic features of the verb. There are a lot of simple and more difficult means how to express the duration of the action. By comparing Czech and German parallel texts of the German business press a lot of means of expressing aspects were found. In specialist literature attention has not been paid to some of them so far. Their frequency in specialist and general language differs greatly. At the same time it is pointed out that there is a danger of interlingual interference when translating.
\end{abstract}

Key words: Czech and German business language, means of expressing aspects, interlingual interference

\section{1 Úvodem}

Ačkoliv se slovesným vidům věnuje celá řada autorů, neexistuje jednota ani v hodnocení této jazykové kategorie, ani v terminologii. Riecke (2000:19) dochází dokonce ve svém výkladu slovesných vidů (aktionsarten) v německých gramatikách $\mathrm{k}$ názoru, že dodnes neexistuje jednota $\mathrm{v}$ tom, zda mají aktionsarten pro popis německé gramatiky vůbec význam.

Na rozdíl od teoretických výzkumů se ve vyučovací praxi vidům téměř nevěnuje pozornost. Uhrová a Uher (1971:46) konstatují, že se toto téma ve výuce ignoruje a je pouze předmětem speciálních výzkumů. Tak tomu je dodnes, ačkoliv u této slovesné kategorie existují výrazné rozdíly mezi němčinou a slovanskými jazyky. Podle Materniak-Behrens (2021:195) patří slovesný vid v polštině k jazykovým jevům, které představují při tlumočení vážnou překážku.

\section{Pojmy aspekt a aktionsart}

V bohemistice se rozumí pod pojmem slovesný vid (aspekt) zpo̊sob průběhu slovesného děje (Uhrová a Uher 1971:50). Štícha ho charakterizuje jako možnost „vy- 
jadřovat různými tvary téhož slovesa jako lexikální jednotky protiklad završenosti (dokončenosti) a nezavršenosti (nedokončenosti) děje, a to na bázi téhož pojmového dějového významu" (2013:440). Vid je tedy vedle osoby, způsobu, času, čísla a slovesného rodu základní kategorií každého českého slovesa.

Takovou gramatickou kategorii němčina nemá, což ovšem neznamená, že by průběh děje (tj. aspektualitu) nemohla vyjádřit. Pojmy Aspekt a Aktionsart se v německé odborné literatuře často zaměňují. Stejně jako Jung (1990), Hentschel a Weydt (1990), Riecke (2000) a většina německých gramatik užíváme pro němčinu označení aktionsart jakožto heterogenní komplex lexikálních, syntaktických aj. prostředků, vyjadřujících průběh slovesného děje.

\section{Cíl, korpus a metoda}

Kontrastivně zkoumají české vidy (aspekty) a německé aktionsarten např. Uhrová a Uher (1971 a 1977), Povejšil (1976), Štícha (2003), Schmiedtová (2003), Doležalová (2016) a Tichák (2018). Zjištěné výrazové prostředky aspektuality i uvedené př́íklady (erjagen, verblühen, tänzeln, schluchzen, platzen, tröpfeln, erkämpfen) ukazují, že vycházejí z obecného, popřs. literárního jazyka.

Jakých výrazových prostředků užívá pro vyjádření českých vidů německý odborný jazyk - v našem případě jazyk hospodářský? Které výrazové prostředky se zde vyskytují nejčastěji? Kde dochází při oboustranném překladu k působení interlingvální interference?

Zdrojem našeho výzkumu je Magazín česko-německého hospodářství Plus, odrážející aktuální hospodářské dění. Většina jeho článků vychází paralelně česky a německy. Je určen pro odborníky, ne pro širokou veřejnost. Zkušení překladatelé, rodilí mluvčí, zaručují jeho dobrou jazykovou úroveň. Bylo excerpováno 12 čísel tohoto časopisu v rozmezí let 2017-2020. Byly analyzovány věty, ve kterých jsou české vidy vyjadřovány nejrůznějšími jazykovými prostředky.

Volba vhodného výrazu pro slovesný vid je pro překladatele často tvrdým oříškem. Proto je pro praktickou výuku i překladatelskou praxi užitečné přiblížit široký repertoár jazykových prostředků a postupů při vyjadřování českých vidů v hospodářské němčině.

\section{Vidy v češtině a aktionsarten $v$ němčině}

Většina českých sloves se vyskytuje ve dvou i více tvarech, které mají stejný základní význam, ale liší se videm. Nedokonavá slovesa vyjadřují průběh děje (otvírat, vyvážet), dokonavá ukončení děje (otevřít, vyvézt). Dokonavá slovesa se tvoří od nedokonavých stejně jako v němčině předponami (platit-zaplatit) nebo př́́- 
ponami (zamykat-zamknout), nedokonavá od dokonavých příponami -áva-, -ívaaj. (dodělat - dodělávat). Podobné introverbální prostředky němčina nemá.

I v němčině lze průběh děje vyjádřit. Vycházeje ze sémantiky slovesa rozlišuje Jung (1990:236) pro vyjadřování aktionsarten sémantické skupiny sloves

1. podle časového průběhu děje

a) časově neutrální (durativní) slovesa, označující průběh (arbeiten, suchen)

b) perfektivní slovesa, označující počátek (abfahren), přechod nebo změnu (grünen, faulen) nebo ukončení, výsledek (finden, erreichen).

2. podle druhu děje
a) kauzativní (fällen, senken)
b) zintenzivňující (erledigen, brüllen)
c) zeslabující (lächeln, hüsteln)
d) opakující (tröpfeln, sticheln)

K jazykovým prostředkům aktionsarten podle Junga patř́

1. odvozování a skládání

a) pomocí předpon er-,ent-, ge-, auf-, an- aj. a př́slovcí los a weg, které označují počátek děje (anlaufen, losgehen) nebo výsledek (abreißen, vollziehen),

b) pomocí předpon $b e-, e r-, g e-, v e r-$, zer a prŕdavných jmen a příslovcí, které mají rezultativní aktionsart (bereinigen, vollziehen)

2. kauzativní aktionsart může být vyjádřen přehláskou nebo hláskovou změnou e/i (öffnen - offen, legen - liegen) či odvozením od adjektiv (bleichen - bleich)

3. pomocí př́pon (horchen - hören)

4. opisy, větnými vazbami a př́slovci (Er beginnt zu reden. Sie pflegen mittags zu schlafen. Er putzt sich täglich die Zähne).

5. užitím haben nebo sein (Er hat lange geschwommen. Er ist ans Ufer geschwommen.)

6. časy (plusquamperfektum, futurum II).

Povejšil (1976:96-97) uvádí další výrazové prostř̌edky, odpovídající českému dokonavému a nedokonavému vidu:

- průběhové a stavové pasivum (Die Angaben sind registriert. Údaje jsou registrovány. - Die Angaben wurden registriert. Údaje byly registrovány.)

- sloveso v perfektu nebo plusquamperfektu pro vyjádření změny stavu (Die Wasserleitung ist/war eingefroren. Vodovod zamrzl.)

- perfektivní tvar vyjadřující výsledek (Der Baum ist verblüht. Strom odkvetl.) 
- slovesa beginnen, anfangen, aufhören $+z u+$ infinitiv (Er begann zu weinen. Rozplakal se.)

Nejproduktivnějším prostředkem vyjadřování průběhu děje je podle Uhrové a Uhra (1971:69) a Schmiedtové (2013:190-213) jak v němčině, tak i v češtině prefixace. Těžištěm vyjadřování vidu $\mathrm{v}$ češtině jsou podle Uhrové a Uhra introverbální prostředky, u aktionsarten $\mathrm{v}$ němčině naproti tomu prostředky analytické (pomocná a funkční slovesa aj.) Jinými slovy: Co se v češtině vyjádří jedním jediným vid rozlišujícím slovesem, $\mathrm{k}$ tomu jsou $\mathrm{v}$ němčině zapotřebí delší syntaktické konstrukce, analytické slovesné tvary, př́slovce a jiné heterogenní jazykové prostředky.

\section{Výrazové prostředky aspektuality v českém a německém hospodářském jazyce}

$\mathrm{V}$ německém hospodářském tisku jsou výše uvedené prostředky vyjadřování aspektuality zastoupeny různě a některé se nevyskytují vůbec. Na druhé straně zde najdeme jazykové prostředky, které $\mathrm{v}$ odborné literatuře uváděny nejsou a které souvisejí s charakteristickými mluvnickými jevy odborného jazyka, jako jsou nominální vyjadřování, verbonominální vazby, trpný rod aj.

\subsection{Předponová slovesa}

Četným českým předponovým slovesům odpovídají v němčině rovněž předponová slovesa s perfektivním (dokonavým) významem:

Sie steigen aus dem Auto aus, das Auto findet selbstständig einen Parkplatz und parkt ein. Vystoupíte z auta, a to si samo najde parkovací místo a zaparkuje. (2020, září, 28)

Předponová slovesa si často významem odpovídají (Mitarbeiter anlernen - zaučit pracovníky, Investitionen einstellen - pozastavit investice, den Trend unterschätzen - podcenit trend, Bewerbungsverfahren erleichtern - ulehčit výběrovému ř́zení). $\mathrm{V}$ některých případech jsou ale tvořeny kolokace $\mathrm{s}$ významově odlišnými, rovněž předponovými slovesy (Aufträge brachen ein - zakázky se propadly, Auswirkungen abfedern - zmírnit dopady, mit neuen Verfahren zurechtkommen - poradit si s novými postupy). Pro vyjádření dokončeného děje tedy nestačí znalost předponového slovesa, ale je třeba znát i správnou kolokaci.

Dále je třeba dbát nato, že mají četná německá slovesa jak dokonavý, tak i nedokonavý význam, takže zde pro vyjádření jednorázového děje není na rozdíl od češtiny zapotřebí předponového slovesa. $V$ češtině je jednorázovost navíc vyjádřena př́íslovcem, které ovlivňuje vid: 
Vor zwei Jahren fuhren sie mit dem autonomen Bus. Před dvěma léty se svezli autonomním autobusem. (2020, listopad, 52)

So etwas lernt man nicht von einem Tag zum anderen. To se člověk nenaučí ze dne na den. (2018, listopad, 22)

Wir haben noch einmal dokumentiert, was wir ohnehin machen. Jen jsme ještě jednou zdokumentovali, co už stejně děláme. (2017, únor, 21)

Na asymetrické užívání předpon je třeba ve výuce upozornit, nebot’ mají studující tendenci přiřadit každému českému předponovému slovesu předponové sloveso $\mathrm{v}$ němčině. Vzhledem $\mathrm{k}$ rozmanitosti předpon $\mathrm{v}$ češtině $\mathrm{i} v$ němčině lze prefixaci označit za nejproduktivnější prostředek $\mathrm{k}$ vyjadřování českých vidů v hospodářské němčině.

\subsection{Verbonominální vazby}

Jedním z nejčastějších prostředků vyjadřování aspektuality jsou v našem korpusu verbonominální vazby. Kompenzují nedostatek terminativních (dokonavých) sloves v př́tomném čase (Leiss 1992:271):

Es ist schwierig, im ausländischen Markt $\mathbf{F u} \boldsymbol{\beta}$ zu fassen. Je náročné proniknout na zahraniční trh. (2019, únor/březen, 32)

Jeder kann zu sauberer Umwelt einen Beitrag leisten. Každý může přispět $k$ čistotě ovzduší. (2020, listopad, 24)

Vedle jednoduchých sloves a jim odpovídajících verbonominálních vazeb (erfüllen - in Erfüllung gehen, schlagen - einen Schlag versetzen, beanspruchen - in Anspruch nehmen, lernen - Lehren ziehen) existují verbonominální vazby, jejichž protějškem není jednoduché imperfektivní sloveso, jako např. Stellung nehmen, zur Kenntnis nehmen, Maßnahmen treffen, Bescheid sagen/geben/wissen aj.

Kromě verbonominálních vazeb majících perfektivní význam, tu jsou i vazby s durativním významem, především spojení se sein a haben + příslovce, signalizující trvání:

Alukov ist weiter auf Wachstumskurs. Společnosti Alukov se stále daří. (2017, záŕí, 58)

Die Regierung hat die Bedürfnisse des Arbeitsmarktes langfristig im Blick. Vláda potřeby trhu dlouhodobě sleduje. (2020, listopad, 15)

I když jsou verbonominální vazby dlouhé a působí těžkopádně, vystihují často nejlépe průběh děje českých sloves - jeho začátek, trvání či zakončení. 


\subsection{Náhrada větným členem}

V mnoha prípadech jsou české věty, často součásti souvětí, v ekvivalentních německých větách nahrazovány odpovídajícím větným členem (př́slovečné určení, podmět, př́ivlastek). Jde vesměs o perfektivní (dokonavá) slovesa, takže lze tuto náhradu považovat za výrazový prostředek aspektuality:

Im Rückblick würde ich mehr Sprachen lernen. Když se ohlédnu zpět, myslím, že jsem se měl víc učit jazykům. (2020, listopad, 70)

Die Probefahrer können ein direktes Feedback zum Auto geben. Ti, kdo absolvovali zkušební jízdu, mohou auto prímo ohodnotit. (2018. červen, 23)

Das verringert die Wettbewerbsfähigkeit der hier beheimateten Firmen. To ztěžuje konkurenceschopnost firem, které se zde usídlily. (2019, ř́jen, 39)

Nahrazením celé věty, vyjadřující ukončený (méně často probíhající) děj jedním větným členem, je děj zhuštěn, zkondenzován. Často jsou tímto větným členem podstatná jména slovesná (Rückgang, Umgang, Eintritt, Eröffnung, Abschaltung aj.). Tento $\mathrm{v}$ odborné literatuře dosud nezmíněný způsob vyjadřování českých vidů je projevem tendence $\mathrm{k}$ nominálnímu vyjadřování $\mathrm{v}$ němčině, zatímco si čeština libuje ve verbální formulaci. S tím souvisí i rozmanitost českých sloves, kterým v němčině odpovídají opisy s haben + podstatné jméno:

Frauen haben eine höhere Lebenserwartung. Ženy se dožívají vyššího věku. (2017, záríi, 36)

Wer hat das Glück, eine solche Betriebskantine zu haben? Komu se poštěstí mít takovou závodní jídelnu? (2020, červen, 6)

Beim Consulting haben unsere Dienstleistungen eine Lebensdauer von zwei Jahren. V poradenství nám služby vydrží v průměru dva roky. (2020, březen, 14)

Při překladu do němčiny je třeba tendenci ke kondenzaci respektovat. Studující mají často sklon k české verbální formulaci, ačkoliv je stručný německý ekvivalent syntakticky jednodušší. Při překladu do češtiny naopak překládají doslova, i když v češtině existují výstižná jednoduchá slovesa.

\subsection{Náhrada přítomným časem}

Ukončený děj, vyjádřený $\mathrm{v}$ češtině dokonavým slovesem $\mathrm{v}$ minulém čase, se v němčině často vyjadřuje slovesem v prézentu. Uplynulý děj je tak prezentován jako stav nebo děj, který stále ještě trvá. Nejčastěji se volí pro současný stav nebo děj významově odlišné durativní sloveso: 
Tschechien ist der größte Standort der Gesellschaft. V České republice byl vybudován největší výrobní závod společnosti. (2019, únor/březen, 37)

Digitalisierung und Industrie 4.0 gehören mittlerweile zu unserem täglich Brot. Digitalizace a průmysl 4.0 se již staly našim denním chlebem. (2017, únor, 3).

Besonders schlecht schneidet die Bundesrepublik ab. Špatné hodnocení si vysloužila Spolková republika. (2019, duben, 6)

Střídání minulého a přítomného času ukazuje, že volba času záleží na úhlu pohledu a hranice mezi oběma časy je plynulá. Nahrazením dokonavých českých sloves $\mathrm{v}$ minulém čase německými durativními slovesy v prézentu je zdůrazněn dnešní stav, popř. výsledek děje.

\subsection{Způsobové sloveso + infinitiv}

Dokonavému českému slovesu může v němčině odpovídat i spojení způsobového slovesa (nejčastěji können) + infinitiv, přičemž je ukončený děj často zvýrazněn příslovečným určením:

Auch beim German Brand Award 2018 konnte das Unternehmen punkten. Společnost zabodovala také v soutěži German Brand Award 2018. (2018, listopad, 44)

Eine Grundregel wusste ich später in meiner eigenen Agentur zu schätzen. Jedno základní pravidlo jsem později ocenil ve vlastní agentuře. (2019, prosinec, 62)

An den IT-Support kann man sich gewöhnen. Na IT-podporu si zvyknete. (2020, březen, 27)

Ukončený děj je vyjádřen jako schopnost, děj uskutečnit. V obou jazycích se užívají významově stejná slovesa. I tato možnost vyjádření českého vidu dosud zůstala nepovšimnuta.

\subsection{Vazby machen/werden + přídavné jméno}

Dalším produktivním zpo̊sobem vyjadřování českého vidu je v němčině spojení machen + přídavné jméno:

Lebensmittel machen satt, halten gesund oder machen krank. Jídlo nás nasytí, udrží zdravé nebo nás o zdraví připraví. (2020, červen, 3)

Einmal fuhren wir in die Slowakei und machten die Software erst im Auto fertig. Jednou jsme jeli na Slovensko a software jsme dodělávali až v autě. (2020, březen, 41)

Wodurch kann die Öffentlichkeit mit diesem Thema besser vertraut gemacht werden? Jaké jsou další cesty, jak veřejnost s tímto tématem lépe seznámit? (2020, listopad, 28) 
Př́́davné jméno se často vyskytuje v komparativu:

Geld macht alles leichter. Peníze mnohé usnadní. (2017, únor, 3)

DTIHK hat die Mittlerfunktion übernommen, um die Grenze durchlässiger zu machen. ČNOPK převzala roli prostředníka, aby pomohla zprůchodnit uzavřené hranice. (2020, červen, 38)

Vedle tranzitivních vazeb s machen se pro vyjádření dokonavého vidu užívá spojení werden + př́́davné jméno:

Man möchte immer allen gerecht werden. Člověk se chce zavděčit všem. (2020, březen, 22)

Die Stückzahlen werden künftig kleiner. Počty vyrobených kusů poklesnou. (2019, ř́ijen, 22)

Wenn man in die Wirtschaftsgeschichte zurückschaut, ist immer alles schneller geworden, nicht langsamer. Pokud se ohlédneme do historie hospodářství, vždy se všechno zrychlovalo, ne zpomalovalo. (2020, březen, 26)

Ve stejné funkci - vyjádření dokonavého děje - se objevuje i sloveso sein:

Sie waren sich einig, dass die Privatisierung ein Erfolg war. Shodli se na tom, že privatizace byla úspěšná. (2020, březen, 44)

Im ersten Monat waren sie in fünf Unternehmen erfolgreich. V prvním měsíci uspěli v pěti firmách. (2017, únor, 40)

Je pochopitelné, že jsou tyto strukturní rozdíly mezi oběma jazyky př́činou interferenčních chyb. Při překladu do němčiny studující obvykle (marně) hledají adekvátní sloveso $v$ němčině. Při překladu do češtiny naopak překládají slovo za slovem, ačkoliv německému spojení odpovídá zvláštní české sloveso.

\subsection{Plusquamperfektum, futurum II a perfektum pro vyjádření budoucího času}

Vyjadřování aspektuality pomocí těchto časů, uváděné často v odborné literatuře Uhrová a Uher (1971:65), Povejšil (1976:96-97), Schmiedtová (2003:199, 203) aj. - hraje v našem korpusu nepodstatnou roli. Častěji se vyskytuje pouze plusquamperfektum, zejména při vyjadřování v minulosti ukončených dějů:

1996 war schließlich die Zeit gekommen. 1996 nastal konečně ten správný čas. (2020, březen, 40) 
Sie hatten schon kurz über digitale Lösungen gesprochen. Už jste krátce zmínil smart řešení. (2018, červen, 17)

\section{8 České opisné tvary pro vyjadřování vidů}

K výrazovým prostředků českých vidů patří také opisné tvary se slovesy přestat/dokázat/dařit se/snažit se aj. + infinitiv významového slovesa. I tyto tvary vyjadřují způsob průběhu děje, popř. vztah k jeho průběhu:

Sklad přestal vydávat zboží. Das Lager lieferte keine Waren mehr. (2020, březen, 41)

Dokáže české školství na takový byznys připravit? Bereitet das tschechische Schulsystem auf ein solches Business vor? (2020, březen, 16)

Jak se vám daří nové, mladé zaměstnance dlouhodobě udržet ve firmě? Wie binden Sie neue junge Mitarbeiter langfristig an das Unternehmen? (2017, únor, 20)

U ekvivalentů českých opisných tvarů vidů je v němčině patrná snaha vyvarovat se delších infinitivních vazeb. Sloveso, vyjadřující vztah k ději, se vesměs vynechává a věta přeformuluje. Jednoduchý infinitiv se však ponechává:

Seznámíte se s řadou firem, které Ostravu dokáží ocenit. Sie lernen eine Menge Firmen kennen, die Ostrava zu schätzen wissen. (2018, červen, 3)

Uvidím, jak se podaří prosadit moje záměry. Ich werde zuerst sehen, wie sich meine Vorhaben durchführen lassen. (2018, červen, 20)

Opisné tvary s infinitivem významového slovesa podle Uherová a Uher (1971:68) ukazují, že se čeština pro vyjadřování vidovosti nemusí vždy omezit na izolované sloveso.

Vedle výše uvedených možností vyjadřování českých vidů v hospodářské němčině je třeba zmínit ještě

- průběhový a stavový trpný rod

Die höchsten Löhne wurden in der Finanz- und Versicherungsbranche ausgezahlt. Nejvyšší mzdy byly vypláceny v peněžnictví a pojištovnictví. (2017, únor, 7) Ale: Die Löhne sind schon ausgezahlt. Mzdy už jsou vyplacené.

Průběhovému pasivu však mohou v češtině odpovídat podle kontextu dokonavá i nedokonavá slovesa (Dort wurden die ersten Computer erzeugt. Tam byly vyrobeny první počítače. Ale: Hier wurden früher Computer erzeugt. Tady byly dříve vyráběny/tady se dřive vyráběly počítače.), což je při překladu do němčiny zdrojem četných interferenčních chyb.

- $\operatorname{sein}+\mathrm{zu}+$ infinitiv 
2018 war ein Rückgang zu verzeichnen. 2018 jsme zaznamenali pokles. (2019, únor, 12)

- haben $+\mathrm{zu}+$ infinitiv

Es ist eine der größten Herausforderungen, mit der die Unternehmen zu kämpfen haben. Je to jedna z největších výzev, se kterou se firmy potýkají. (2018, červen, 69)

- příslovce

Die Anfänge sind für Startups oft schwer. Začátky bývají pro startupy těžké. (2017, únor, 37)

Wir passen unsere Kommunikation andauernd an. Vylad'ujeme naší komunikaci. (2019, duben, 12)

\section{Shrnutí}

Porovnáním paralelních německých a českých textů hospodářského risku byly zjištěny jazykové prostředky pro vyjadřování české vidovosti v německém hospodářském jazyce. $\mathrm{K}$ nejproduktivnějším prostředkům patří prefixace, verbonominální vazby, nahrazování celých vět jedním větným členem, náhrada minulých časů prézentem, opisné tvary způsobového slovesa + infinitiv, vazby sloves $m a$ chen/werden + př́idavné jméno aj.

U jednotlivých výrazových prostředků je upozorňováno na potíže a nebezpečí interlingvální interference, se kterou se ve výuce a překladatelské praxi neustále setkáváme.

\section{Literatura}

Andersson, Sven-Gunnar. Gibt es Aspekte im Deutschen? Dl1.cuni.cz $>\bmod >$ resource $>$ view $\Delta$ PFF.

DoležAlovÁ, KateŘina. (2016). Der Aspekt im Tschechischen und seine Ausdrucksmöglichkeiten im Deutschen. Jihočeská univerzita, Pedagogická fakulta, České Budějovice.

Hentschel, Elke, Weydt, Harald. (1990). Handbuch der deutschen Grammatik. Berlin - New York. Jung, WALTER (1990). Grammatik der deutschen Sprache, 10. Auflage, Mannheim - Leipzig.

LEISS, Elisabeth (1992). Die Verbalkategorie des Deutschen. Ein Beitrag zur Theorie der sprachlichen Kategorisierung. In Studia Linguistika Germanica, Hrsg. Von STEFAn SonderRegger 31, WaLter DE GRUYTER, Berlin. New York.

MATERniAK-BEHRENS, MieczslaWA. (2012). Zur Wiedergabe von aspektbedingten Informationen beim Dolmetschen. Sprachenpaar: Polnisch - Deutsch. In: Im Anfang war das Wort I, Linguistische Treffen in Wroclaw, vol. 8, herausgegeben von IwonA BARToszewicz, JoAnnA SzczeK, ARTur TworeK, Neisse Verlag Wroclaw - Dresden, S. 162-199.

Polenz, Peter. (1963). Funktionsverben im heutigen Deutsch. Sprache in der rationalisierten Welt. In: Beiheft 5 zur Zeitschrift „Wirkendes Wort“, Düsseldorf.

POVEJŠIL, JAROMír (1976). Vyjadřování vidu a způsobu slovesného děje v němčině a češtině. In: Studies in Modern Philology 2., Praha. Kabinet cizích jazyků Československé akademie věd, S. 93-108. 
RIECKE, JöRG (2000). Über die Darstellung der Aktionsarten in den Grammatiken des Deutschen. In: Sammelband der Arbeiten der Philosophischen Fakultät der Brünner Universität Studia minora facultatis philosophicae universitatis brunnensis R5, S. 19-36.

Schmiedtová, BARBora. (2003). Aspekt und Tempus im Deutschen und Tschechischen: eine vergleichende Studie. In jahrbuch-brucken.de > Brucken-2003-Schmiedtova.pdf $\Delta$ PDF (S. 186-215).

ŠTícha, FrantišEK. (2003). Česko-německá srovnávací gramatika. Argo: Prag.

TichÁк, ViKToR. (2018). Effektivität und effektive Aspektonymie. Ein kontrastiver Beitrag zur tschechisch-deutschen Aktionsartenforschung. In: Brünner Beiträge zur Germanistik und Nordistik 32/2018/1, S. 115-129 https://dot.org/10.5817/BBGN2018-1-10.

UhrovÁ, Eva, UhER, FrantišEK. (1971). Zur Interpretation der Aktionsarten im Deutschen. In: Brünner Beiträge zur Germanistik und Nordistik I, Brno, S. 454-73.

UhrovÁ, Eva, UHER, FrantišEK. (1977-1978). Opakovanost děje v němčině. In: Sborník prací Filozofické fakulty brněnské univerzity Studia minora facultatis philosophicae universitatis brunnensis A 25/26, S. 11-119

cs.wikipedia.org/wiki/Slovesný_vid

www.zchechency.org.slovnik/VID

\section{Autorka}

Prof. PhDr. Věra Höppnerová, DrSc., e-mail: vera.hoppnerova@vse.cz, je členkou katedry německého jazyka na Vysoké škole ekonomické a na Pedagogické fakultě Západočeské univerzity v Plzni. Zabývá se výzkumem hospodářského jazyka z hlediska frazeologie, lexikologie, slovotvorby a interlingvální interference. Je autorkou 244 odborných článků v českých i zahraničních odborných časopisech. Široké veřejnosti je známá jako autorka více než 70 učebnic němčiny pro vysoké, odborné, jazykové školy a gymnázia, jako např. „Zrádná slova v němčině“, „Deutsch im Gespräch“, „Obchodujeme německy“ nebo „Begleiter durch die deutsche Grammatik." 